\title{
ARTICLE Selective cytoprotective effect of histamine on doxorubicin- induced hepatic and cardiac toxicity in animal models
}

\author{
DJ Martinel Lamas ${ }^{1,2}$, MB Nicoud $^{2}$, HA Sterle ${ }^{3}$, E Carabajal $^{1}$, F Tesan ${ }^{1}$, JC Perazzo ${ }^{4}$, GA Cremaschi ${ }^{1,3}$, ES Rivera ${ }^{1}$ and VA Medina ${ }^{1,2}$
}

\begin{abstract}
The aim of the present work was to evaluate the potential protective effect of histamine on Doxorubicin (Dox)-induced hepatic and cardiac toxicity in different rodent species and in a triple-negative breast tumor-bearing mice model. Male Sprague Dawley rats and Balb/c mice were divided into four groups: control (received saline), histamine (5 mg/kg for rats and $1 \mathrm{mg} / \mathrm{kg}$ for mice, daily subcutaneous injection starting $24 \mathrm{~h}$ before treatment with Dox), Dox ( $2 \mathrm{mg} / \mathrm{kg}$, intraperitoneally injected three times a week for 2 weeks) and Dox+histamine (received both treatments). Tissue toxicity was evaluated by histopathological studies and oxidative stress and biochemical parameters. The combined effect of histamine and Dox was also investigated in vitro and in vivo in human MDA-MB-231 triple-negative breast cancer model. Heart and liver of Dox-treated animals displayed severe histological damage, loss of tissue weight, increased TBARS levels and DNA damage along with an augment in serum creatine kinase-myocardial band. Pretreatment with histamine prevented Dox-induced tissue events producing a significant preservation of the integrity of both rat and mouse myocardium and liver, through the reduction of Dox-induced oxidative stress and apoptosis. Histamine treatment preserved anti-tumor activity of Dox, exhibiting differential cytotoxicity and increasing the Dox-induced inhibition of breast tumor growth. Findings provide preclinical evidence indicating that histamine could be a promising candidate as a selective cytoprotective agent for the treatment of Dox-induced cardiac and hepatic toxicity, and encourage the translation to clinical practice.
\end{abstract}

Cell Death Discovery (2015) 1, 15059; doi:10.1038/cddiscovery.2015.59; published online 21 December 2015

\section{INTRODUCTION}

Cancer is a major public health concern worldwide. Overall, there were 14.1 million new cases and 8.2 million deaths in $2012{ }^{1}$

Radiation and chemotherapy are widely used treatments for cancer. Despite their antitumoral effects controlling the primary tumor and metastasis, both therapeutic modalities can produce toxicity to normal tissues and frequently, their related adverse effects outweigh clinical benefits and worsen patient's quality of life.,

The anthracycline doxorubicin (Dox) is a highly effective anti-neoplastic agent, which intercalates in DNA and inhibits topoisomerase II. Dox is one of the most commonly systemic treatments to improve several adult and also pediatric cancers, including both hematological and solid tumors. ${ }^{4-6}$ Unfortunately, its clinical efficacy of Dox is hampered by dose-related toxicities, such as hematopoietic suppression and hepatotoxicity; although the most serious side effect is the life-threatening cardiomyopathy. The onset of cardiotoxicity may be delayed and become evident years after finalizing chemotherapy. ${ }^{3,4,6}$ Multiple cytotoxic mechanisms are involved in the pathogenesis of Dox-induced cardiotoxicity. However, a large body of evidence indicates that Dox-induced oxidative stress remains the cornerstone, as evidence by reactive oxygen species (ROS) induced oxidative damage such as lipid peroxidation. ${ }^{3,4,6}$ In addition, hepatotoxicity represents a common and severe side effect, in which oxidative stress also has a pivotal role., ${ }^{7,8}$

At present, there are no specific and effective therapeutic agents for Dox-associated cardio- or hepatotoxicity. Thus, the study of compounds that could improve the therapeutic index of chemo- and radiotherapy, reducing their side effects on healthy tissues without affecting their anti-neoplasic effects, is urgently needed. ${ }^{3,9-11}$ In this regard, previous data demonstrate that histamine administration was safely used in different experimental models as a radioprotective agent of normal radiosensitive tissues, including small intestine, salivary glands and bone marrow. ${ }^{12-15}$

Furthermore, histamine acts as an anti-proliferative agent in different cancer types. It was reported that histamine and histamine $\mathrm{H} 4$ receptor (H4R) agonists inhibit proliferation of two human breast cancer cell lines in vitro and in vivo, augmenting tumoral apoptosis. ${ }^{16-21}$ Similar anti-tumor effects of H4R agonists were observed in three different human melanoma cell lines ${ }^{22}$ and in cholangiocarcinoma experimental models. ${ }^{23}$

It is important to highlight that histamine not only exhibits antitumor effects but also potentiates the ionizing radiation action in breast cancer cells. Histamine produces a radiosensitizing action involving enhanced radiation-induced oxidative DNA damage and apoptosis and increasing DNA double-strands breaks. Furthermore, histamine was able to enhance in vivo the effect of gamma radiation, augmenting the exponential tumor doubling time of triple-negative breast cancer (TNBC) developed in nude mice. ${ }^{18,24}$

Based on these evidences, the aim of the present work was to evaluate the potential protective effect of histamine on Doxinduced hepatic and cardiac toxicity in different rodent species and in a triple-negative breast tumor-bearing mice model.

\footnotetext{
${ }^{1}$ Laboratory of Radioisotopes, School of Pharmacy and Biochemistry, University of Buenos Aires, Junín 956 PB, Buenos Aires, Argentina; ${ }^{2}$ Laboratory of Cellular and Molecular Biology, Institute for Biomedical Research (BIOMED), School of Medical Sciences, Pontifical Catholic University of Argentina (UCA), and the National Scientific and Technical Research Council (CONICET), Buenos Aires, Argentina; ${ }^{3}$ Neuroimmunomodulation and Molecular Oncology Division, Institute for Biomedical Research (BIOMED), School of Medical Sciences, Pontifical Catholic University of Argentina (UCA), and the National Scientific and Technical Research Council (CONICET), Buenos Aires, Argentina and ${ }^{4}$ Department of Pathophysiology, School of Pharmacy and Biochemistry, University of Buenos Aires, Buenos Aires, Argentina.

Correspondence: VA Medina (vmedina@ffyb.uba.ar)

Received 11 September 2015; revised 16 October 2015; accepted 21 October 2015; Edited by A Rufinit
} 

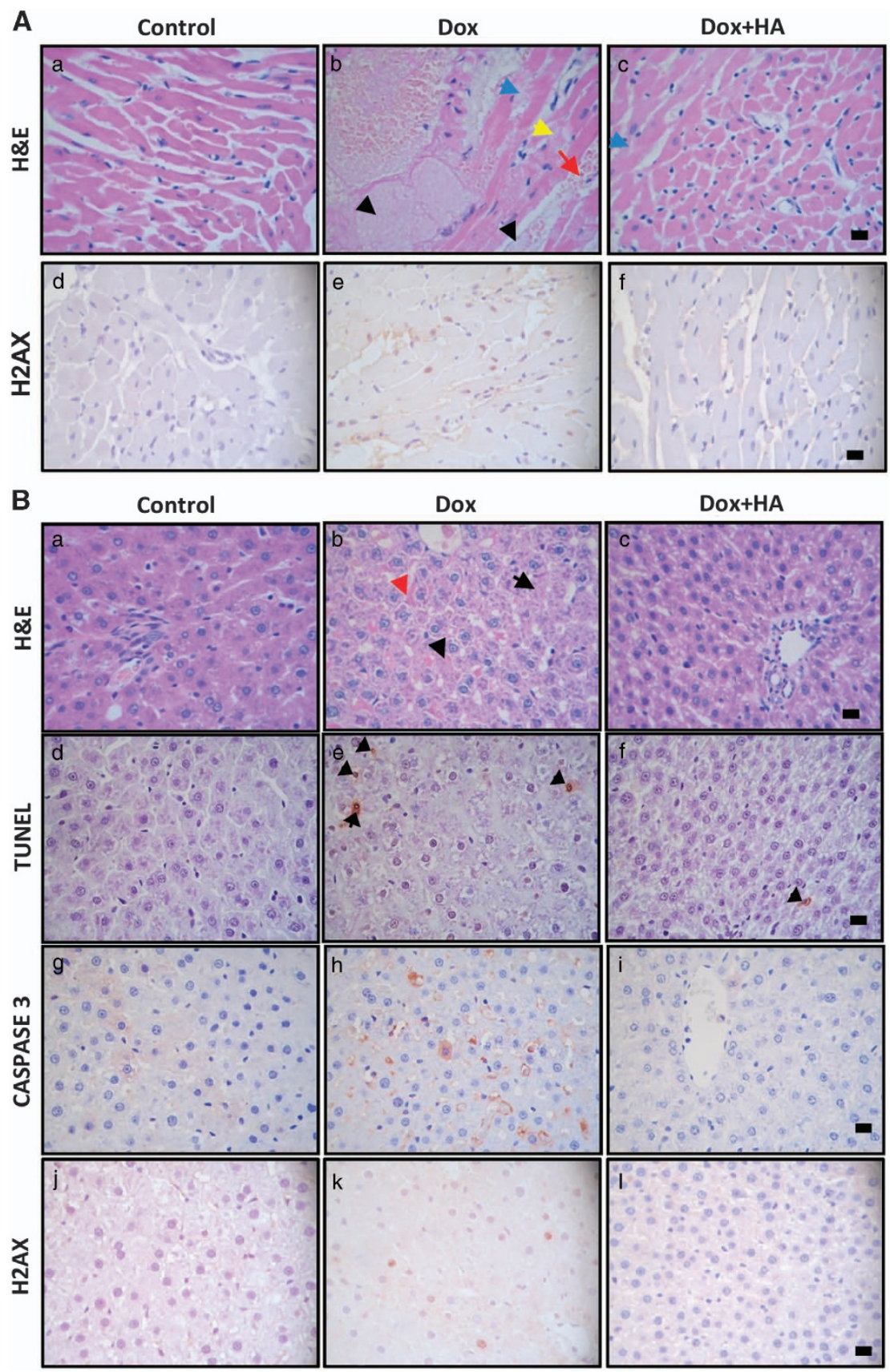

Figure 1. Histamine decreases doxorubicin-induced cardiotoxicity and hepatotoxicity in rats and mice. (A) (a, d) Normal histological appearance of untreated heart. (b, e) Heart of Dox-treated animals displaying focal necrotic cell death (black arrow), congestion-hemorrhage (red arrow), myocytolysis (yellow arrow) and myofribrillolysis (blue arrow) with fibrils de-arrangement. (c, f) Heart of Dox+HA-treated animals showing evident preservation of heart structure with reduced myofibrillolysis (blue arrow) and muscle bands with normal appearance. (a-c) Representative H\&E stained specimens and (d-f) immunohistochemical images of $\gamma H 2 A X$ sections are shown. (B) (a, $d, g$, j) Normal histological appearance of liver from untreated animals. (b, e, h, k) Liver of Dox-treated rats displaying de-arrangement of hepatic trabecula (red arrow), cellular edema and focal necrosis (black arrow). (c, f, i, l) Liver of Dox+HA-treated animals showing preservation of tissue structure with mild cellular edema. $(\mathrm{a}-\mathrm{c})$ Representative H\&E-stained sections are shown. (d-f) Representative immunohistochemical images of TUNEL, ( $\mathrm{g}-\mathrm{i}$ ) caspase 3 and $(\mathrm{j}-\mathrm{I}) \mathrm{\gamma H} 2 \mathrm{AX}$ in paraffin-embedded liver specimens. Arrows indicate TUNEL-positive cells. (Six to eight rats per group). (C) (a) Normal histological appearance of WT mice untreated heart. (b) Heart of Dox-treated animals displaying vascular damage with perivascular edema, myofribrillolysis (blue arrow), cell recruitment (yellow arrows) and focal necrosis (black arrows). (c) Heart of Dox+HA-treated animals showing minimal focal damage with muscle bands with normal appearance. (d) Normal histological appearance of untreated heart of $\mathrm{H}_{4 \mathrm{R}^{-/}}$ mice. (e) Heart of Dox-treated H4R ${ }^{-/-}$mice displaying myofibrillolysis (blue arrow), cell mobilization (yellow arrows) and focal necrosis (black

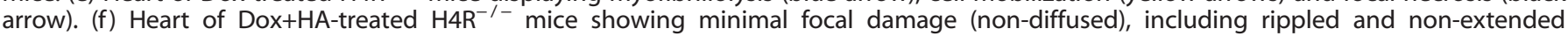
myofibrillolysis, with vasculature with normal appearance. (D) (a) Normal histological appearance of untreated liver of WT mice. (b) Liver of Dox-treated animals displaying two different areas, an extended necrotic region and a normal area, between them cellular mobilization as a band (arrow) (c) Liver of Dox+HA-treated WT mice showing almost normal characteristics. (d) Normal histological appearance of liver of untreated $\mathrm{H}_{4 \mathrm{R}^{-\prime-}}$ mice. (e) Liver of Dox-treated $\mathrm{H}_{4} \mathrm{R}^{-1-}$ displaying reduced histological damage with focal and non-diffuse necrotic areas

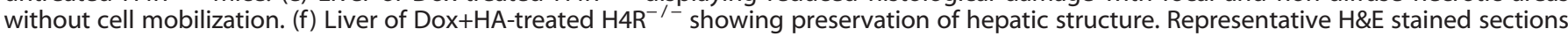
are shown. x630 Original magnification. Scale bar, $20 \mu \mathrm{m}$. Inset: image at x100-fold magnification. (8-12 Mice per group). 
C
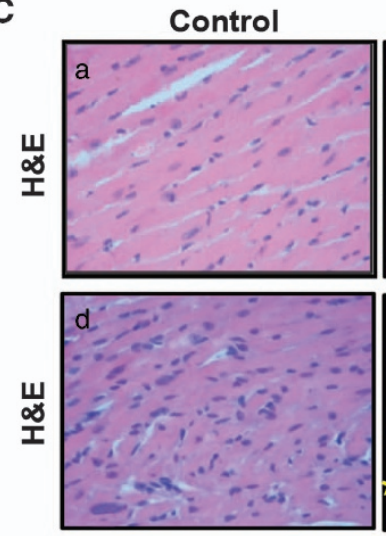

D
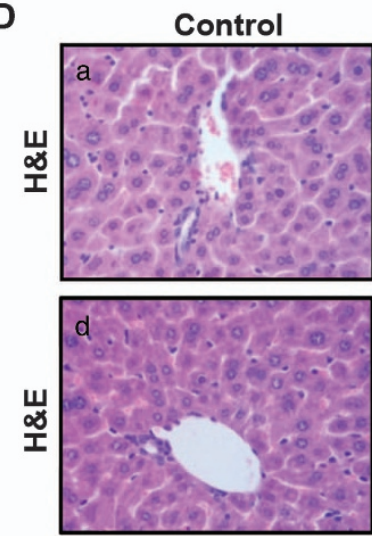

Dox



Dox
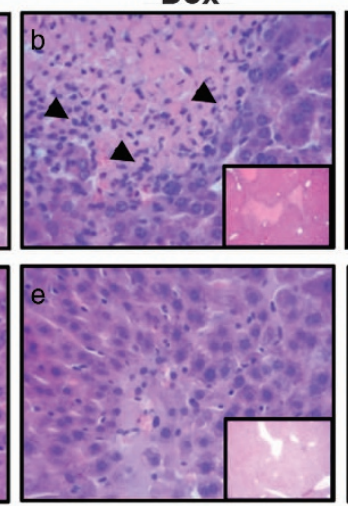

Dox+HA

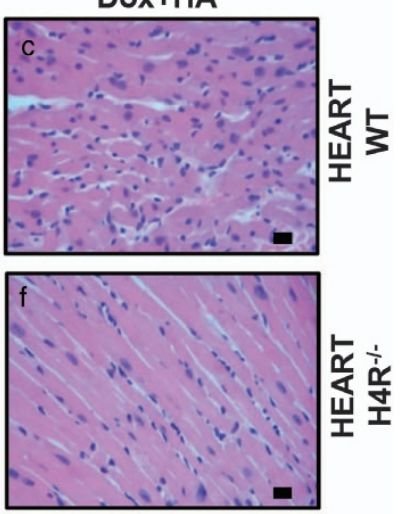

Dox+HA

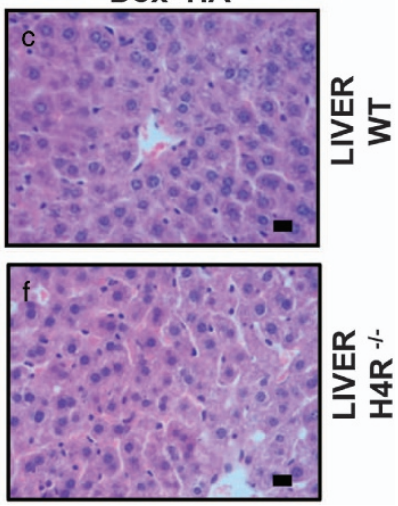

Figure 1. Continued.

\section{RESULTS}

Histamine reduces Dox-induced cardiotoxicity in rats

It is well known that a major adverse side effect associated with Dox clinical usage is the onset of cardiomyopathy., 3,6 Cardiotoxicity was evaluated by both histopathological studies and oxidative stress and biochemical parameters. Serum creatine kinasemyocardial band (CK-MB) and aspartate aminotransferase (AST) are considered excellent markers for cardiac injury and are used to evaluate Dox-cardiotoxicity in different experimental models. ${ }^{6,25}$

The heart of Dox-treated rats showed a severe histological damage with congestion, rippled myocytes, reduction of striated muscle bands, hemorrhagic areas, myocytolysis and focal necrosis, along with enhanced expression of DNA damage marker $\mathrm{yH} 2 \mathrm{AX}$, effects that were markedly reduced by histamine administration (Figure $1 A$ ).

Dox-induced cardiotoxicity was also manifested by an increase in CK-MB and cholesterol levels and a decrease in the ratio of heart weight to body weight (Figures $2 a-c$ ). In addition, myocardial tissue from Dox-treated rats showed significant increases in TBARS production and SOD levels (Figures $2 d$ and $f$ ).

On the other hand, histamine significantly alleviated the increase in lipid peroxidation and SOD activity, as well as serum CK-MB activity and blocked the decrease in heart weight while enhanced thiol levels in Dox-treated rats (Figures 2a-f). Non-significant changes were observed in catalase activity (Supplementary Table S1) and unexpectedly a significant decrease in AST levels were observed in both Dox and Dox+HA groups in rats and mice (Supplementary Table S2) as it was previously observed. ${ }^{25}$

Histamine ameliorates Dox-induced hepatotoxicity in rats Dox produced drastic cellular abnormalities in the liver, including focal necrosis and fibrosis, sinusoidal atrophy and edema and reduced liver weight (Figures $1 \mathrm{~B}$ and 3a). Dox also significantly increased apoptosis, which was evaluated by the TUNEL assay and activated caspase 3 , and also phosphorylation of $\mathrm{H} 2 \mathrm{AX}$ in the liver of treated rats (Figures $1 \mathrm{~B}$ and $3 \mathrm{C}$ ). The combined treatment with histamine markedly preserved hepatic weight and tissue structure, which only showed mild vacuolization (Figures $1 \mathrm{~B}$ and $3 \mathrm{a}$ ), reduced DNA damage and the number of apoptotic cells, exhibiting similar characteristics to the untreated liver (Figures 1B and 3C).

Kupffer cells are long-lived tissue macrophages located in sinusoids with a pronounced endocytic and phagocytic capacity and important host-defense functions. ${ }^{26}$ Dox significantly diminished the number of Kupffer cells in hepatic lobules, effect that was blocked with histamine treatment (Figure $3 \mathrm{~b}$ ). In addition, a significant increase in lipid peroxidation was observed in the liver of Dox-treated rats, while histamine treatment prevented this effect (Figure 3d). Non-significant changes were observed in hepatic thiol content, while the combination of histamine and Dox increased SOD activity (Figures $3 e$ and f). Both histamine and Dox administration increased hepatic catalase activity (Supplementary Table S1). No evident changes were observed upon histamine administration (Figures 3a-f).

Histamine reduces cardiac and hepatic toxicity in wild-type and $\mathrm{H}_{4} \mathrm{R}^{-1-}$ mice

The former described experiments suggested that histamine produced cytoprotective effects on Dox-induced toxicity in rat heart and liver. To confirm its protective effects, another animal experimental model of Balb/c mice was further investigated.

Hearts of Dox-treated WT mice exhibited the expected histopathological abnormalities, including focal necrosis and vascular damage that were accompanied by a significant increase in cardiac lipid peroxidation compared with saline-treated control mice (Figures 1C and 4a). Histamine markedly reduced 

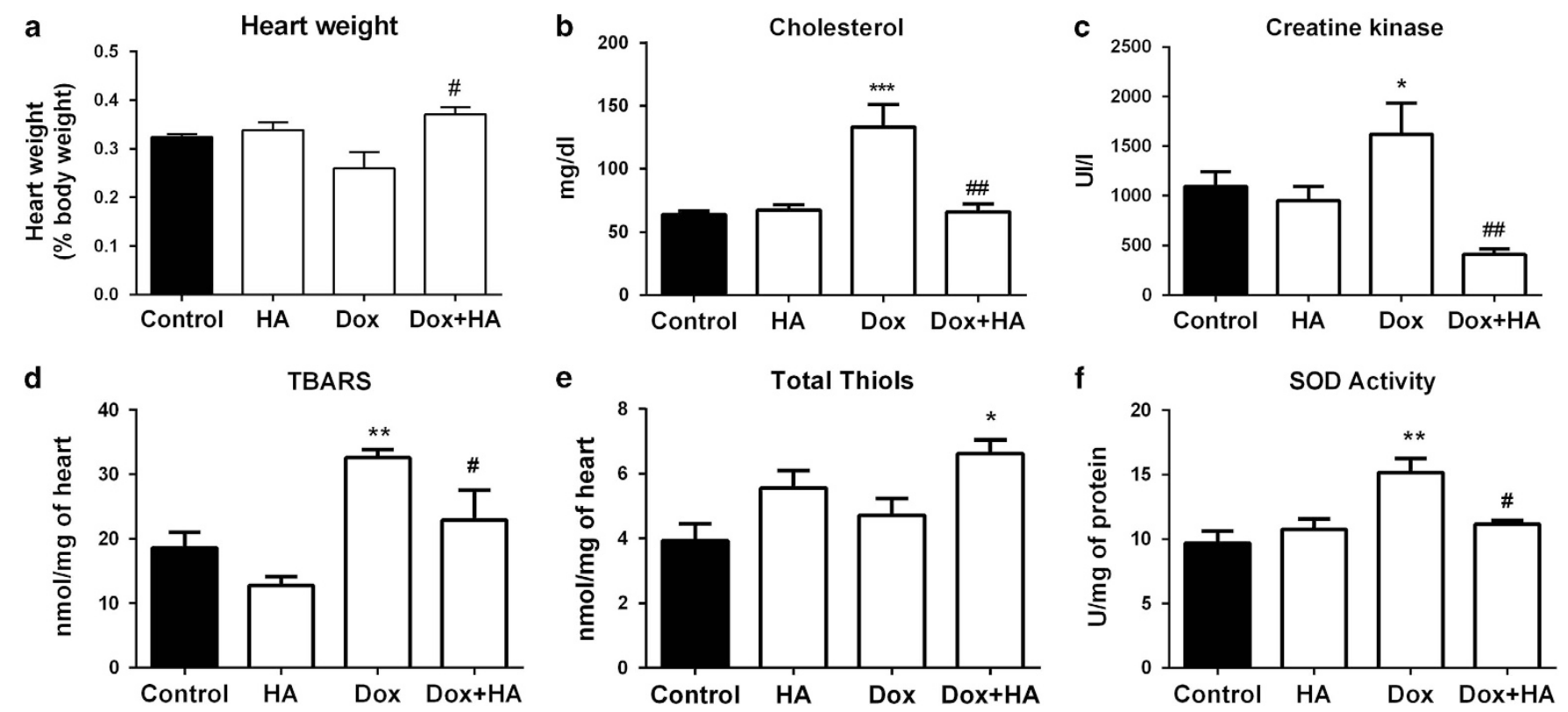

Figure 2. Histamine blocks doxorubicin-induced cytotoxic and oxidative damage in rat's heart. (a) Heart weight determined as percentage of body weight. (b) Serum cholesterol levels. (c) Serum CK-MB levels. (d) TBARS levels expressed as nmol/mg of cardiac tissue. (e) Thiols content expressed as $\mathrm{nmol} / \mathrm{mg}$ of tissue. (f) SOD activity expressed as $\mathrm{U} / \mathrm{mg}$ of heart proteins. (Six to eight rats per group, ${ }^{*} P<0.05,{ }^{*} P<0.01$, $* * * P<0.001$ versus control; ${ }^{\#} P<0.05,{ }^{\#} P<0.01$ versus Dox).



d

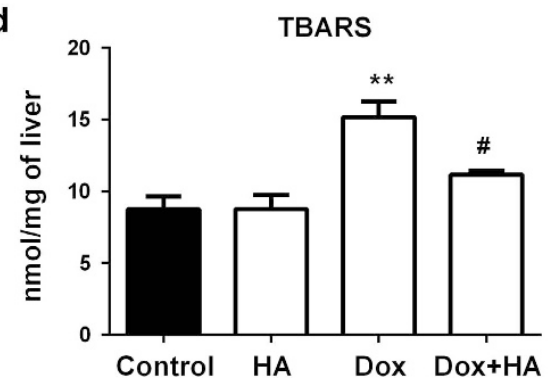

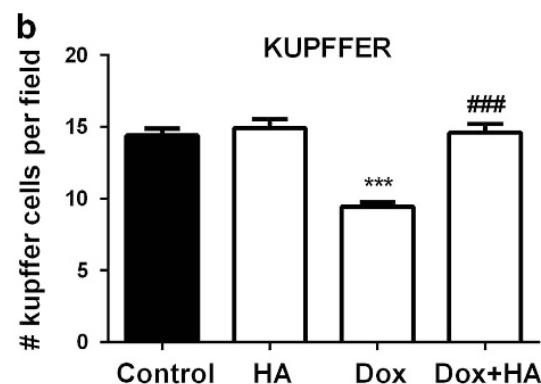


f

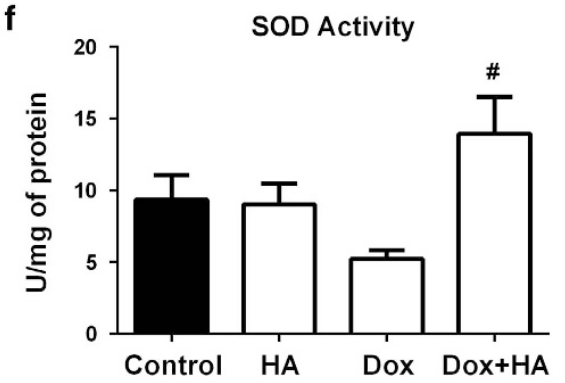

Figure 3. Histamine alleviates doxorubicin-induced cytotoxic and oxidative damage in a rat's liver. (a) Liver weight determined as percentage of body weight. (b) The number of Kupffer cells and (c) the number of TUNEL-positive cells were determined by counting 10 random fields. (d) TBARS levels expressed as nmol/mg of cardiac tissue. (e) Thiols content expressed as nmol/mg of tissue. (f) SOD activity expressed as $\mathrm{U} / \mathrm{mg}$ of liver proteins. (Six to eight rats per group, ${ }^{*} P<0.05$, ${ }^{* *} P<0.01$, ${ }^{* *} P<0.001$ versus control; ${ }^{\#} P<0.05$, ${ }^{\# \# \#} P<0.001$ versus Dox).

histopathological changes, preserving muscle bands and vasculature and also blunted the Dox-induced rise in TBARS levels (Figures $1 \mathrm{C}$ and $4 \mathrm{a}$ ).

In agreement with previous data, Dox exhibited a severe hepatotoxic effect in Balb/c mice, which was evidenced by many areas of necrosis surrounded by cellular mobilization, and enhanced TBARS levels (Figures 1D and 4b). As it was shown in rat model, histamine prevented both hepatic histological and oxidative damage in Dox-treated mice (Figures 1D and 4b).

Interestingly, $\mathrm{H}_{4} \mathrm{R}^{-/-}$mice were less affected by Dox-induced histopathological alterations and lipid peroxidation in heart and liver compared with WT mice (Figures $1 C$ and D and $4 a$ and b). Nevertheless, histamine administration was able to prevent the manifested histological damage in heart and liver of Dox-treated $\mathrm{H}_{4} \mathrm{R}^{-/-}$mice (Figures $1 \mathrm{C}$ and $\mathrm{D}$ ).

Histamine enhances Dox-induced anti-proliferative effects on MDA-MB-231 triple-negative breast cancer cells

To determine whether histamine could affect the anti-tumoral effect of Dox and considering that this chemotherapeutic agent is one of the first-line treatments in $\mathrm{TNBC}_{1}{ }^{27}$ the combined effect of 
histamine and Dox on proliferation in MDA-MB-231 cells was first investigated. Clonogenic assay demonstrated that both single agents induced a dose dependent inhibition on the proliferative capacity of MDA-MB-231 TNBC cells ${ }^{16}$ and histamine $(10 \mu \mathrm{M})$ increased Dox inhibitory effect (Figure 5a). According to the calculated $\mathrm{Cl}$ using the Chou-Talalay method, ${ }^{28}$ Dox and histamine combination showed synergistic anti-tumoral activity $(\mathrm{Cl}<1)$ tested at a 50\% effective dose, calculated at Dox $(5 \mathrm{nM})$ and histamine $(10 \mu \mathrm{M})(\mathrm{Cl}=0.41)$ or Dox $(10 \mathrm{nM})$ and histamine $(10 \mu \mathrm{M})$ combinations $(\mathrm{Cl}=0.16)$.

The incorporation of BrdU was further evaluated as a measurement of active proliferation. The $48 \mathrm{~h}$ combined treatment of Dox and histamine resulted in a modest, but significant, additional reduction of the incorporation of BrdU compared with Dox used alone (Figure 5b).

Consistently, both TUNEL and Annexin V assays show a significant increase in the rate of apoptotic cell death in Doxtreated cells, effect that was enhanced by the combined treatment with histamine (Figure $5 \mathrm{c}$ and $\mathrm{d}$ ).

Furthermore, the combined treatment of Dox and histamine downmodulated cyclin D1 and E2 mARN levels, whereas upregulated the expression of p27 (Kip1) and p21 (Figure 5e).

Dox may exert its anti-neoplastic effect, in part, by causing DNA damage ${ }^{5}$ and $8-\mathrm{OHdG}$ is a major type of oxidative DNA damage marker. ${ }^{29}$ Results demonstrate that both single agents and the drug combination increased 8-OHdG formation (Figure $5 \mathrm{~g}$ ). In addition, single treatments alone induced phosphorylation of $\mathrm{H} 2 \mathrm{AX}$, a marker of DNA double-strand breaks, ${ }^{24}$ while the combination treatment enhanced DNA damage further (Figure 5i).

Dox was reported to induce ROS generation in several tumor cells. ${ }^{4,6}$ Dox, histamine and the combination treatment increased ROS production (Figure $5 \mathrm{~h}$ ).

Similar effects were observed in the hormone-dependent MCF-7 breast cancer cells, in which Dox reduced proliferation dose dependently and the combined treatment with histamine enhanced this inhibitory effect on cell growth, while also increased Dox-induced ROS levels (Supplementary Table S3).

The mitogen-activated protein kinase such as extracellular signal-regulated kinase (ERK) and p38 are involved in cell growth, death and breast cancer chemoresistance. ${ }^{30}$ Therefore, Dox and histamine effects on phospho-ERK1/2 (p-ERK1/2) and phosphop38 (p-p38) were assayed by western blot. Both compounds induced the phosphorylation of ERK1/2 and p38 in MDA-MB-231 cells (Figure 5f).
Histamine induces a selective effect on doxorubicin cardiac and hepatotoxicity in triple-negative breast cancer-bearing mice The combination therapy of Dox and histamine was further studied in vivo in a human TNBC model induced in nude mice by injection of MDA-MB-231 cells. Dox significantly reduced tumor size and increased doubling time, while the combined treatment of Dox and histamine enhanced significantly Dox-mediated decrease in the rate of proliferation (Figures $6 \mathrm{~A}$ and $\mathrm{B}$ ).

Histopathological analysis shows that Dox decreased the number of mitosis per field and cellularity. The combined treatment of Dox and histamine almost completely decreased mitosis per field and further diminished tumor cellularity that was replaced by extracellular matrix (Figures $6 C$ and D).

Consistently, histamine potentiated Dox-induced increased tumoral apoptosis and reduced PCNA proliferation marker expression, while increasing DNA oxidative damage evaluated by $8-\mathrm{OHdG}$ formation (Figures $6 \mathrm{C}$ and D).

As it was demonstrated in the other experimental models described, Dox produced severe cardiotoxicity in nude mice evidenced by numerous areas of myocytolysis and necrosis. Again, histamine administration counteracted the deleterious effect of Dox on heart, reducing histological damage (Figure 6E).

Dox also produced marked hepatic histological alterations, including sinusoidal atrophy and fibrosis, effects that were alleviated by the combination with histamine (Figure 6E).

\section{DISCUSSION}

Dox is one of the most effective anticancer drugs, but its clinical use is limited by life-threatening cardiotoxicity. Apart from its therapeutic cytotoxic effect on cancer cells through interacting DNA, Dox-induced ROS formation and oxidative damage. Both effects are particularly important in the pathogenesis of cardiac and hepatic injury. ${ }^{3-5,10}$ At present, no clinically proven treatment is established for Dox-induced cardiomyopathy. Therefore, novel approaches and the development of safe chemoprotective drugs against detrimental effects of Dox on normal tissues without hindering its anti-tumor activity are of upmost importance together with their translatability to clinical practice. ${ }^{3,4,10}$

In the present study we show that Dox produces severe histopathological changes in heart of Sprague Dawley rats and also Balb/c mice, effects that are accompanied by a marked increase in cardiac lipid peroxidation, SOD activity and DNA damage and in serum CK-MB and cholesterol levels and also by a decrease in heart's weight, findings similar to those in other studies.,31-33 Although lipid peroxidation and CK-MB level are undoubtedly increased, several studies have reported no a

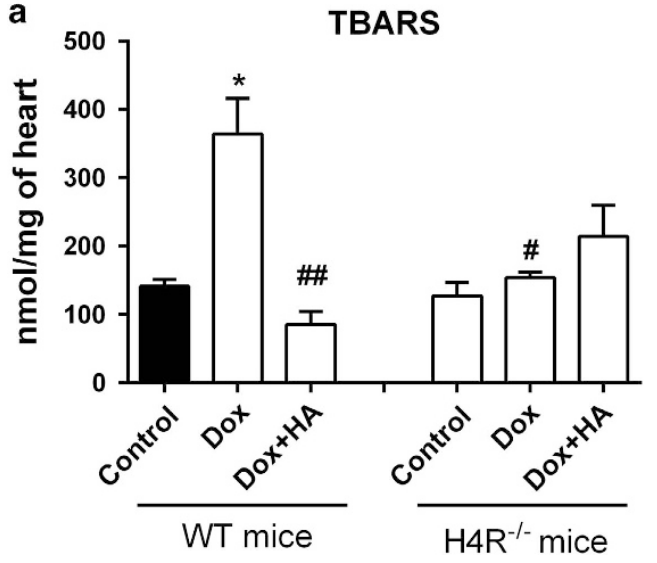

b

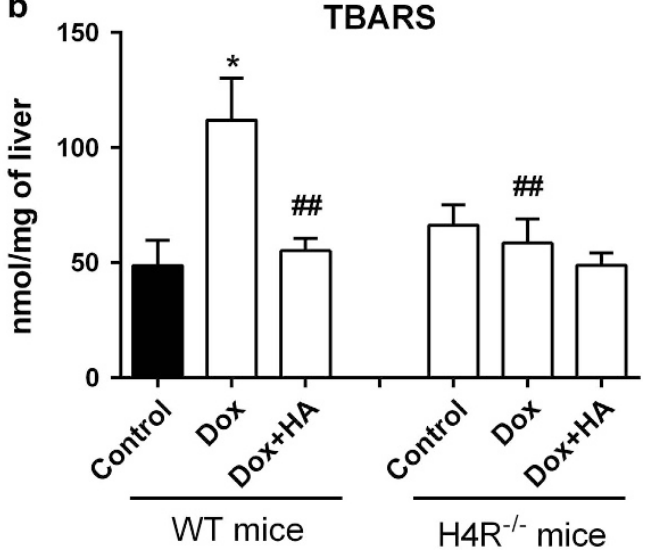

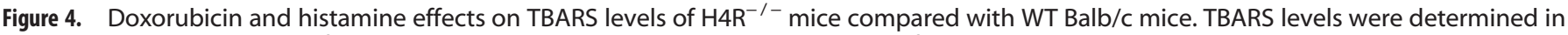
mice (a) heart and (b) liver of WT and KO mice. Data are expressed as nmol/mg of tissue. (8-12 mice per group, ${ }^{*} P<0.05$ versus WT Control; ${ }^{\#} P<0.05$, ${ }^{\# \#} P<0.01$ versus WT Dox). 


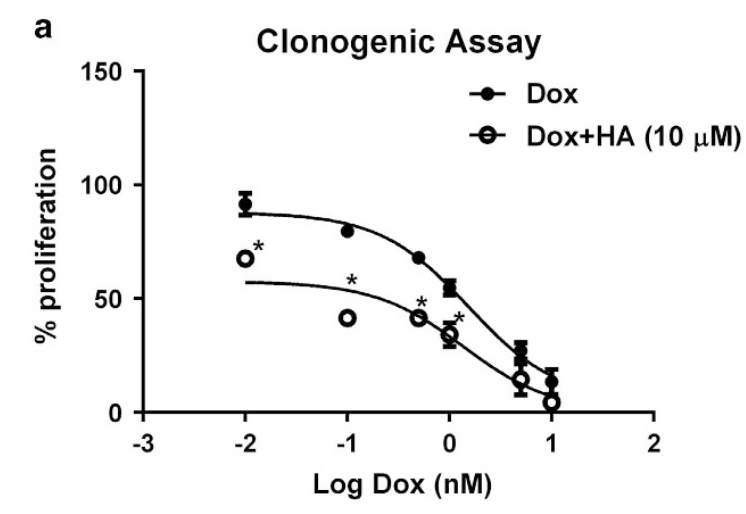

C
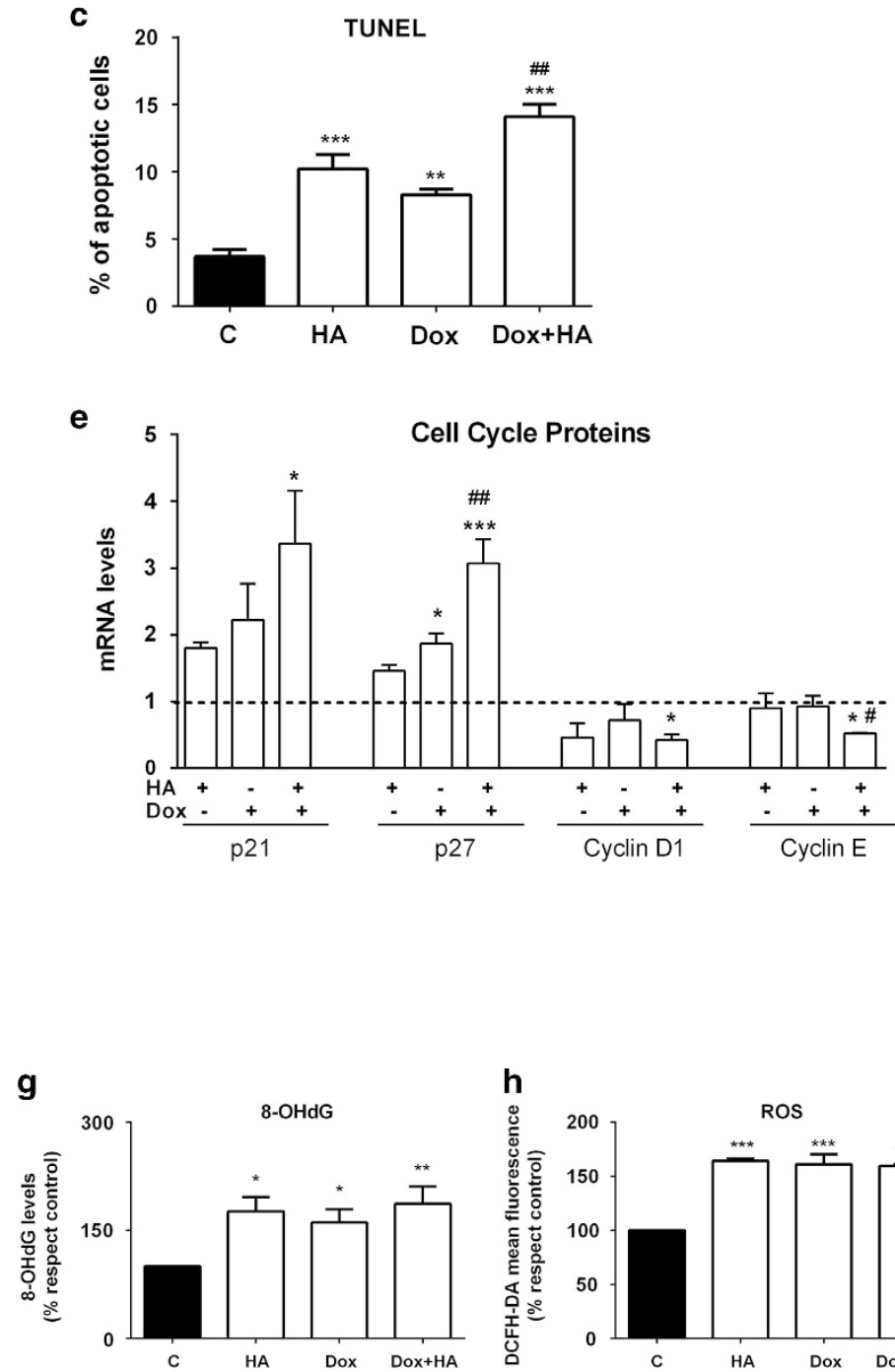



\begin{tabular}{l|c|}
\hline Treatment & $\begin{array}{c}\text { \% of BrdU } \\
\text { incorporation }\end{array}$ \\
\hline Control & $50.7 \pm 4.2$ \\
\hline Dox & $40.8 \pm 1.3^{\star}$ \\
\hline HA & $36.6 \pm 1.8^{\star \star}$ \\
\hline Dox+HA & $30.9 \pm 2.7^{\star \star \star, \#}$
\end{tabular}



f
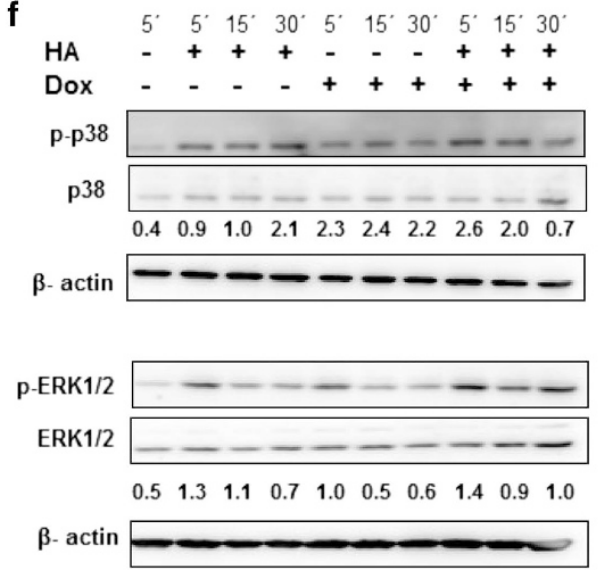

i
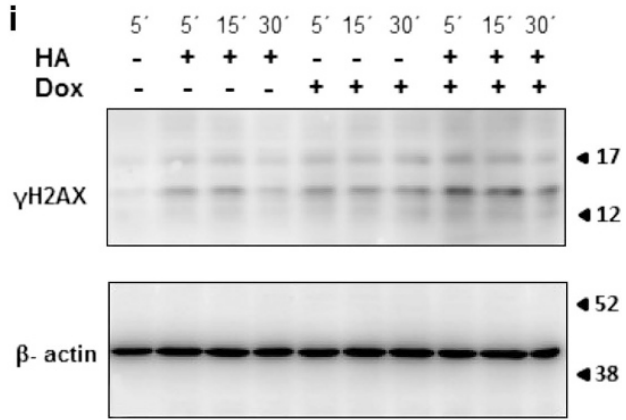

Figure 5. Histamine enhances anti-proliferative properties of doxorubicin in vitro. (a) Proliferation was evaluated by the clonogenic assay in human TNBC MDA-MB-231 cells treated with Dox (0.01-10 nM) in the absence (closed circles) or presence (open circles) of $10 \mu \mathrm{M}$ histamine. Proliferation was expressed as a percentage relative to untreated cells ( $n=3,{ }^{*} P<0.01$ versus Dox; two-way ANOVA and Bonferroni post test). (b) Incorporation of BrdU, (c) TUNEL and (d) Annexin-V staining assays were evaluated in MDA-MB-231 cells that were left untreated (control; C) or were treated with histamine $(\mathrm{HA}, 10 \mu \mathrm{M})$ and/or doxorubicin (Dox, $10 \mathrm{nM}$ ) for $48 \mathrm{~h}$. (e) The mRNA expression levels of p21, p27, cyclin D1 and cyclin E2 were determined $24 \mathrm{~h}$ after treatments using GPCR and the expression levels were normalized to the expression of $\beta$-2-microglobulin. The $\Delta \Delta \mathrm{Ct}$ method was used to calculate the fold change. (g) Oxidative DNA damage was evaluated by measuring 8-OHdG formation and (h) intracellular ROS levels were determined $24 \mathrm{~h}$ after $\mathrm{HA}$ and/or Dox treatments using flow cytometry. $(n=3-5$, $* P<0.05$, ${ }^{* *} P<0.01$, ${ }^{* * *} P<0.001$ versus control; ${ }^{\#} P<0.05$, \#\# $P<0.01$ versus Dox). Time course effects of Dox and $\mathrm{HA}$ on (i) $\gamma \mathrm{H} 2 \mathrm{AX}(15 \mathrm{kDa})$ and (f) phospho-MAPKs (p-ERK1/2, 42/44 kDa and p-p38) were assayed by western blot. Total ERK1/2, p38 and $\beta$-actin (42 kDa) were used as loading control. Semiquantitative analyses of band intensities are shown $(n=2)$. 
A

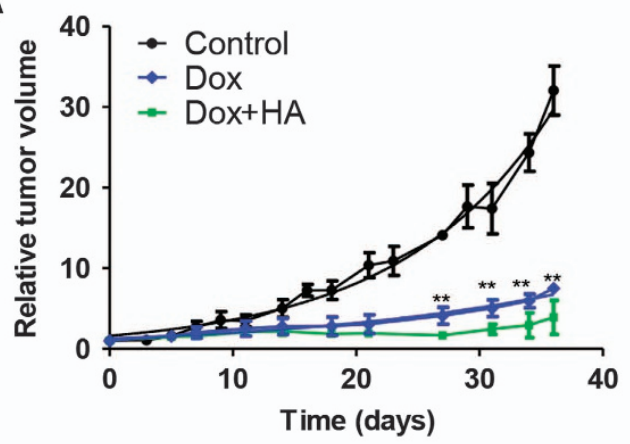

B

\begin{tabular}{cc} 
B & $\begin{array}{c}\text { Tumor Doubling } \\
\text { Time (days) }\end{array}$ \\
\hline Control & $7.7 \pm 0.7$ \\
HA $(5 \mathrm{mg} / \mathrm{kg})$ & $12.6 \pm 1.4^{*}$ \\
Dox $(2 \mathrm{mg} / \mathrm{kg})$ & $20.7 \pm 1.0^{* * *}$ \\
Dox $+\mathrm{HA}$ & $30.9 \pm 1.2^{* * * \ldots}$ \\
\hline
\end{tabular}

C
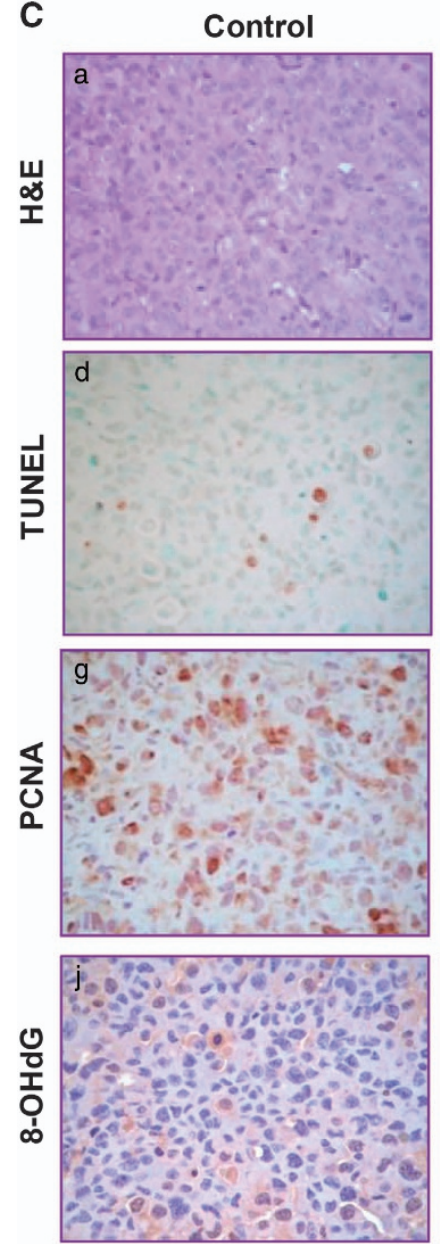

Dox
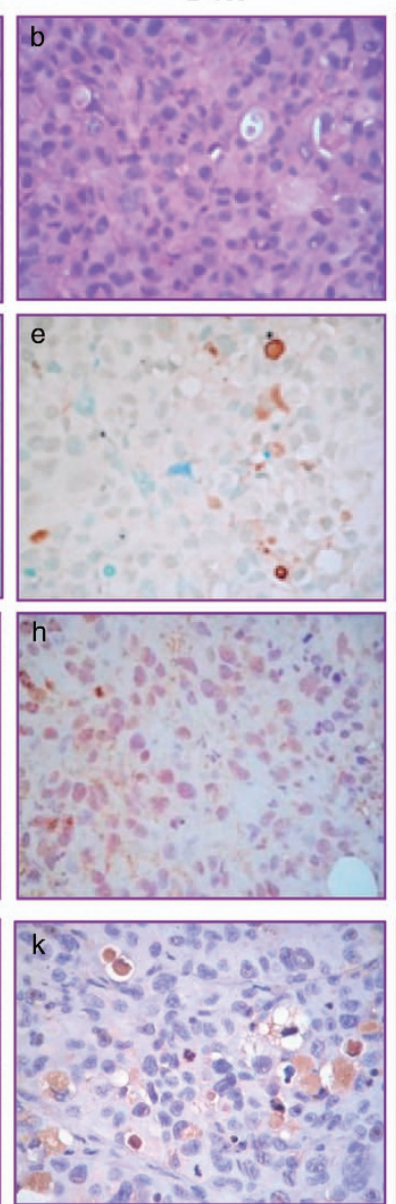

Dox+HA
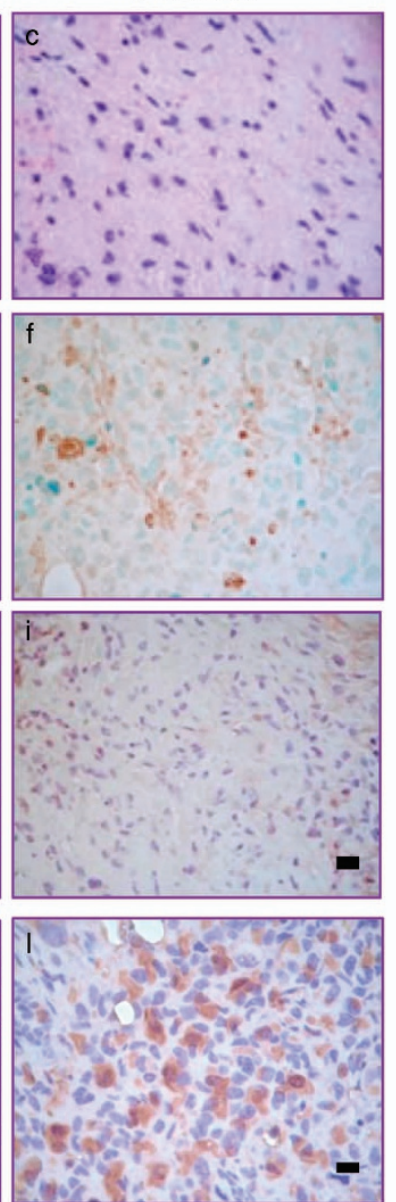

D
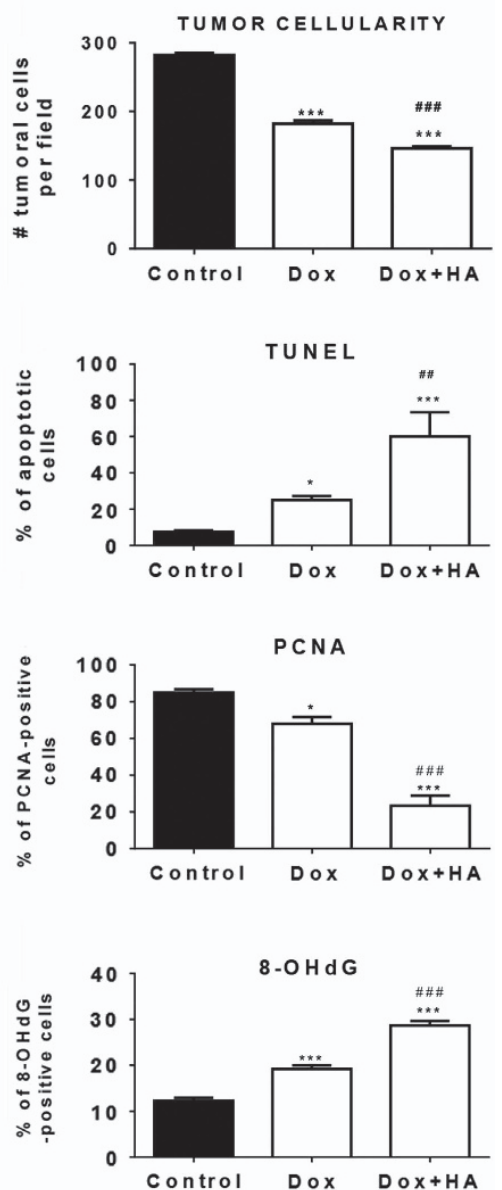

Figure 6. Combined effect of histamine and doxorubicin on triple-negative breast tumors induced in nude mice. (A) Relative tumor volume of the control group versus doxorubicin (Dox, $2 \mathrm{mg} / \mathrm{kg}$ ) or the combination of Dox $(2 \mathrm{mg} / \mathrm{kg})$ and histamine (HA, $5 \mathrm{mg} / \mathrm{kg})$. (6 mice per group, ${ }^{* *} P<0.01$ versus Control; $T$-Test). (B) Median tumor doubling time of each group is depicted numerically $\left({ }^{*} P<0.05,{ }^{* * *} P<0.001\right.$ versus Control; ${ }^{\# \#} P<0.01$ versus Dox. $T$-Test). (C) Histopathological and immunohistochemical analyses of tumor tissues. (a-c) Representative H\&E-stained sections are shown. (a) Untreated tumors presented undifferentiated adenocarcinoma cells with marked anisokaryosis and anisocytosis. (b) Dox increased necrosis and the nuclear optical density. (c) The combined treatment Dox+HA reduced tumor cellularity, with evident nuclear hyperchromasia, that was replaced by extracellular matrix. Representative immunohistochemical images of (d-f) TUNEL, (g-i) PCNA and $(j-l) 8-d O H G$ in paraffin-embedded tumor tissues. x630 Original magnification. Scale bar, $20 \mu \mathrm{m}$. (D) The number of tumor cells and the percentage of TUNEL, PCNA and 8-OHdG-positive stained cells were quantified by counting 10 random fields. ${ }^{*} P<0.05, * * * P<0.001$ versus

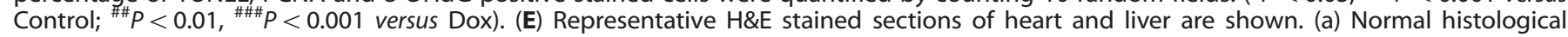
appearance of untreated heart. (b) Heart of Dox-treated animals displaying severe myocytolysis (red arrow), areas of necrosis (black arrow) and reduced striated muscle bands. (c) Heart of Dox+HA-treated animals showing preservation of the structure with reduced myocytolysis, nuclei and muscle bands with normal appearance. (d) Normal histological appearance of untreated liver. (e) Liver of Dox-treated animals displaying focal necrosis (black arrow), sinusoidal atrophy (white arrow), inflammatory infiltrates, and fibrosis (red arrow). (f) Liver of Dox+HA-treated animals showing reduced sinusoidal disarrangement, displaying similar characteristics of the untreated liver. x1000 Original magnification. Scale bar, $20 \mu \mathrm{m}$. 
E
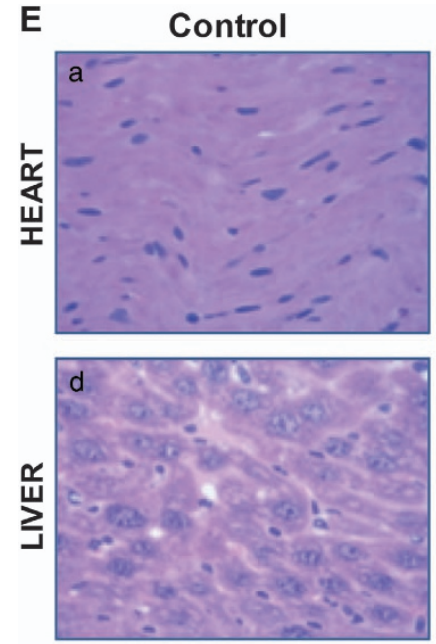

Dox
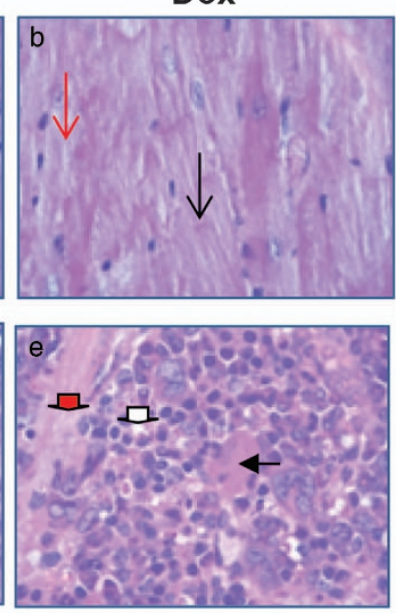

Dox+HA
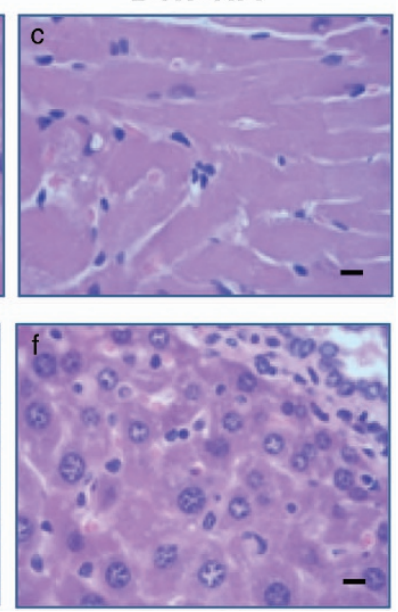

Figure 6. Continued.

significant change, increase or decrease activities of SOD and catalase, the major enzymes participating in free radical metabolism, depending on Dox concentration, intervals of administration, time of evaluation or experimental model. ${ }^{4,31}$

Remarkably, pretreatment with histamine prevented all Doxinduced tissue events producing a significant preservation of both rat and mouse myocardium integrity, likely through a reduction of Dox-induced oxidative stress. This hypothesis is reinforced by our previous works, which demonstrated the protective effect of histamine on ionizing radiation-induced injury of different sensitive tissues through a modulation of antioxidant enzymes and reduction of genotoxic damage. ${ }^{12-15}$ Present data show, for the first time, the potential cytoprotective effect of histamine against Dox-induced cardiotoxicity by reducing oxidative stress and also DNA damage (by $\gamma \mathrm{H} 2 \mathrm{AX}$ marker). In this regard, recent studies demonstrated that histamine through the activation of H3R produces significant protective effects, alleviating norepinephrine-induced arrhythmias that characterize myocardial ischemia/reperfusion (I/R). ${ }^{34}$ In addition, the H3R agonist imetit produces a cardioprotective action, improving isoproterenolinduced hemodynamic, plasma cardiac biomarkers, tissue antioxidant status and histopathology. ${ }^{35}$ On the other hand, activation of mast cell H4R, possibly by mast cell-derived histamine during I/ $\mathrm{R}$ produces cardioprotective anti-renin angiotensin system effects with reduction of norepinephrine release, alleviating reperfusion arrhythmias. $^{36}$

Hepatotoxicity is another frequent side effect of Dox chemotherapy with a significant impact on patients' outcomes. ${ }^{7,8}$ In agreement with previous data, ${ }^{7,37}$ Dox also increases hepatic lipid peroxidation and apoptosis, while reduces liver's weight and SOD activity. These effects paralleled with serious histopathological alterations. Pretreatment with histamine significantly prevents all the evaluated Dox-induced toxic manifestations, preserving liver structure. Therefore, histamine represents an effective approach to reduce Dox-induced hepatotoxicity. In addition, histamine blocks the Dox-induced reduction of Kupffer cells, liver macrophages involved in the control of tumor growth and infection. ${ }^{2,38}$ Ongoing studies of dynamic hepatobiliary scintigraphy showed a reduced ${ }^{99} \mathrm{~m}$ Tc-disida extraction with Dox administration, effect that was blocked by histamine (FT, unpublished data), suggesting that histamine could prevent Dox-induced hepatic dysfunction.

In support to this hypothesis, other authors reported that histamine effectively protects liver against I/R-induced histological, functional and oxidative damage. Histamine effect was not blocked by pretreatment with mepyramine ( $\mathrm{H} 1 \mathrm{R}$ antagonist) or ranitidine ( $\mathrm{H} 2 \mathrm{R}$ antagonist) but was reversed by pretreatment with thioperamide (H3R and H4R antagonist). ${ }^{39}$ Furthermore, histamine effect was mimicked by treatment with clozapine, ${ }^{39}$ an antipsychotic drug that is also considered not only H4R but also H3R agonist. ${ }^{40}$ Therefore, further studies using specific pharmacological blockade and/or genetically H4R knockdown system are needed to confirm the hepatoprotective role of H4R. In line with this data, treatment with clozapine $(1 \mathrm{mg} / \mathrm{kg}$, s.c.) reduced histological and oxidative stress injury in Dox-treated rats, although to a lesser extend compared to histamine treatment (DJML, unpublished data).

Importantly, we found that in heart and liver of $\mathrm{H}_{4} \mathrm{R}^{-/-}$mice, non-significant increase in TBARS levels was observed after Dox administration and a reduced histological damage was shown especially in liver of Dox-treated animals, which exhibited diminished areas of necrosis. Nevertheless, histamine improved histological features in Dox-treated $\mathrm{H}_{4} \mathrm{R}^{-/-}$mice, suggesting in the one hand that another histamine receptor might be involved in histamine cytoprotective effect and on the other hand, that H4R contributed to Dox-induced damage. Our next experiments will focus on the identification of the receptor subtype/s involved in histamine cytoprotection. In addition, considering the role of inflammation in chemotherapy-induced cytotoxicity ${ }^{31}$ and the anti-inflammatory properties of pharmacological H4R blockade in preclinical and clinical studies, ${ }^{40,41}$ we will investigate the effect of H4R antagonists to evaluate whether they could be beneficial to treat Dox side effects. In this regard, we previously demonstrated that pretreatment with the selective H4R antagonist JNJ7777120 reduced radiation-induced genotoxic, oxidative stress and histological damage on small intestine, salivary glands and hematopoietic tissues. $^{42}$

Several protective agents have been investigated to prevent Dox-induced damage in preclinical models. However, none of the strategies has been translated into clinical practice., ${ }^{40,25,31}$ In addition, only some of the published approaches verified whether the treatments compromised Dox therapeutic efficacy. This anthracycline is one of the standards of care in TNBC, which accounts for $15-20 \%$ of all breast cancers and is characterized by poor prognosis. ${ }^{27}$ Thus, we investigated the combined effect of histamine and Dox in MDA-MB-231 TNBC cells. Our study demonstrated that histamine increased Dox-induced anti-tumoral activities not only in vitro but also in vivo. Histamine enhances Dox-induced apoptosis and DNA damage, while modulates p-ERK1/2 and p-p38 expression in MDA-MB-231 cells. Importantly, in the tumor-bearing mouse model we were able to reconfirm the selective cardio and hepatoprotective action of histamine. 
It is important to highlight that histamine has been reported to be relatively a low-toxic compound, well tolerable by both animals of different species at similar or higher concentrations employed at the present study ${ }^{39,43,44}$ as well as cancer patients. Histamine is being used in clinical trials as an adjuvant to immunotherapy. ${ }^{44-46}$

Collectively, present findings indicate that histamine exhibits chemoprotective effects against Dox-induced cytotoxic and oxidative damage in heart and liver. Thus, the combined use of histamine with Dox could be an attractive strategy to improve the therapeutic ratio of Dox. Especially taking into account that histamine treatment also produces the inhibition of tumor growth and the induction of apoptosis without compromising the antitumor activity of Dox and exhibiting differential cytotoxicity. In conclusion, histamine could be a promising candidate as a selective cytoprotective agent for the treatment of cardiac and hepatic toxicity caused by Dox chemotherapy.

\section{MATERIALS AND METHODS}

\section{Animals and treatments}

Male Sprague Dawley rats (200-250 g) and Female athymic nude (NIH $\mathrm{nu} / \mathrm{nu})$ mice $(20-25 \mathrm{~g})$ were purchased from the Division of Laboratory Animal Production, School of Veterinary Sciences, University of La Plata, Buenos Aires, Argentina. Balb/c H4R knockout $\left(\mathrm{H}_{4} \mathrm{R}^{-/}, 6.12955 \mathrm{tm} 1\right.$ [Histamine 4 Receptor] Lex) mice were gifted by Janssen Research \& Development, LLC (NJ, USA) and Balb/c wild-type mice both were obtain from The Jackson Laboratory (Sacramento, CA, USA).

Animals (aged 8-10 weeks) were kept 4-6 per cage and maintained in our animal health care facility at 22 to $24^{\circ} \mathrm{C}$ and $50-60 \%$ humidity on a $12 \mathrm{~h}$ light/dark cycle with food and water available ad libitum. Animal procedures were in accordance with recommendations from the Guide for the Care and Use of Laboratory Animals of the National Research Council, USA, and protocols were approved by the Ethical Committee for the Use and Care of Laboratory Animals of BIOMED (UCA-CONICET).

Doxorubicin (Dox) and histamine (HA) were freshly dissolved in saline solution. Animals were separated into four groups $(n=6-12$ each): control group, HA, Dox and Dox+HA. HA and Dox+HA groups received a daily subcutaneous (s.c.) HA injection for 2 weeks $(1 \mathrm{mg} / \mathrm{kg}$ for BALB/c WT and $\mathrm{KO}$ mice and $5 \mathrm{mg} / \mathrm{kg}$ for rats) starting 1 day before the first dose of Dox $(2 \mathrm{mg} / \mathrm{kg})$ in Dox $+\mathrm{HA}$ group. Dox was administered every other day intraperitoneally (i.p.) in six injections for 2 weeks in Dox and Dox+HA groups. Control group received saline. Animals were sacrificed 1 day after the last dose of Dox. Tumor-bearing nude mice received both treatment (daily s.c. $5 \mathrm{mg} / \mathrm{kg}$ histamine injection and three i.p. injection per week of $2 \mathrm{mg} / \mathrm{kg}$ of Dox) until the end of the experimental period ( 5 weeks). Serum levels of CK-MB, aminotransferases and cholesterol were assessed from an intracardiac blood sample taken at the time of sacrificing the anesthetized animal ('Hospital de Clínicas', University of Buenos Aires, Buenos Aires, Argentina).

\section{Tumor development and growth evaluation}

Tumors of MDA-MB-231 cells were developed as previously described. ${ }^{16}$ When the graft volumes reached $100-150 \mathrm{~mm}^{3}$, xenografted mice were separated in four groups and were treated until killing as described. To evaluate tumor growth the length and width of the subcutaneous tumors were measured using a caliper three times a week. ${ }^{16,24}$ The tumor size was calculated as sphere volume. Tumor growth data were expressed as relative tumor volume (tumor volume measured with respect to initial tumor volume at the beginning of treatment) and analysis was carried out using GraphPad Prism version 5.00. The equation for exponential growth was $Y_{t}=Y_{0} \times \mathrm{e}^{(k \times t)}$, where $Y_{0}$ was the initial relative tumor volume that increased exponentially with a rate constant, $k$. The tumor doubling time was calculated as $0.69 / \mathrm{k}$.

\section{Histopathological and immunohistochemical studies}

Tissues and tumors were removed and were fixed with 10\% neutral buffered formalin and after embedding in paraffin, specimens were cut into serial sections of $4 \mu \mathrm{m}$ thick. Histopathological characteristics were examined after hematoxylin-eosin staining (H\&E).

Immunohistochemistry was performed as it was previously described. ${ }^{17}$ Briefly after blocking, tissues were incubated with primary goat anti-8- hidroxydeoxyguanosine (8-OHdG, 1:200, Millipore, Temecula, CA, USA), mouse anti-proliferating cell nuclear antigen (PCNA, 1:100, DAKOCytomation, Glostrup, Denmark), rabbit anti-phosphorilated histone $\mathrm{H} 2 \mathrm{AX}$ antibody $(\gamma \mathrm{H} 2 \mathrm{AX}$, Cell Signaling Technology, Beverly, MA, USA), or rabbit anti-cleaved caspase 3 (Abcam, 1:100 Cambridge, MA, USA) antibodies overnight in a humidified chamber at $4{ }^{\circ} \mathrm{C}$. Immunoreactivity was detected by using Vectastain ABC Kit (Vector Laboratories INC., Burlingame, CA, USA) according to the manufactures' instructions or with horseradish peroxidase-conjugated anti-goat antibody (1:250, Sigma Chemical Co., St Louis, MO, USA.) and visualized by diamino-benzidine staining (Sigma Chemical Co.).

Apoptotic cells were detected, as earlier reported, ${ }^{12}$ using ApoptagTM plus peroxidase in situ apoptosis Detection Kit (Millipore) according to the manufacturer's instructions.

Light microscopy was performed on an Axiolab Karl Zeiss microscope (Göttingen, Germany). All photographs were taken using a Canon PowerShot G5 camera (Tokyo, Japan). Specimens were assessed and scored to provide a quantitative measurement by using ImageJ, NIH software.

Evaluation of total thiol content, TBARS levels and catalase and SOD activities

The thiobarbituric acid reactive species (TBARS) assay is a well-established method for screening and monitoring lipid peroxidation. The method used in the present study, was described by $\mathrm{Yagi}^{47}$ and adapted as previously reported. ${ }^{42} \mathrm{~A}$ molar extinction coefficient of $\varepsilon=1.56 \times 10^{5} / \mathrm{M} / \mathrm{cm}$ was used for calculations.

Tissue total thiols concentration was estimated by the ability of the sulfhydryl group to reduce 5,5'-dithiobis(2-nitro-benzoic acid) (DTNB, Sigma-Aldrich) according to Tietze ${ }^{48}$ and was described previously by us. ${ }^{42}$ A molar extinction coefficient of $\varepsilon=13.6 / \mathrm{mM} / \mathrm{cm}$ was used for calculations.

Catalase activity was measured spectrophotometrically by monitoring the disappearance of $\mathrm{H}_{2} \mathrm{O}_{2}$ at $240 \mathrm{~nm}$, as it was previously described. ${ }^{42,49}$ A unit of catalase was defined as the disappearance of $1 \mu \mathrm{mol}$ of $\mathrm{H}_{2} \mathrm{O}_{2} / \mathrm{min}$ $(\varepsilon=43.6 / \mathrm{mM} / \mathrm{cm})$.

Superoxide dismutase (SOD) activity was assayed by inhibition of adrenochrome formation rate at $480 \mathrm{~nm}$. One unit of SOD is determined as the amount of enzymatic protein required to inhibit 50\% epinephrine auto-oxidation. ${ }^{42,49}$

\section{Cell culture and proliferation assays}

MDA-MB-231 and MCF-7 cells (American Type Tissue Culture Collection, Manassas, VA, USA) were were maintained and clonogenic assay was performed as previously reported. ${ }^{16,24}$ Cells were seeded in 6-well plates $(1,200$ cells/well) and were treated with Dox $(0.01-1000 \mathrm{nmol} / \mathrm{l})$ alone or with HA $(0.01-10 \mu \mathrm{mol} / \mathrm{l})$ or remained untreated. Cells were incubated for 7 days and were then fixed and stained with $1 \% \mathrm{w} / \mathrm{v}$ toluidine in $70 \% \mathrm{v} / \mathrm{v}$ in ethanol. Cutoff were colonies containing 50 cells or more and data was expressed as a percentage of the untreated wells.

To examine the interaction between histamine and Dox, the isobolanalysis was employed and the combination index $(\mathrm{Cl})$ was determined according to the Chou-Talalay method using CompuSyn software (ComboSyn Inc, NJ, USA). The resulting $\mathrm{Cl}$ theorem offers quantitative definition for additive effect $(\mathrm{Cl}=1)$, synergism $(\mathrm{Cl}<1)$, and antagonism $(\mathrm{Cl}>1)$ in drug combinations ${ }^{28}$

Quantification of cellular DNA synthesis was performed by 5-bromo-2'deoxyuridine (BrdU, Sigma Chemical Co.) incorporation assay as previously described. ${ }^{19}$ Briefly, cells were treated with Dox $(10 \mathrm{nM})$ and/ or HA $(10 \mu \mathrm{M})$ and were maintained up to $48 \mathrm{~h}$ after. $\operatorname{BrdU}(30 \mu \mathrm{mol} / \mathrm{l})$ was added to cultures the last $2 \mathrm{~h}$. Cells were fixed and after denaturing the DNA, cells were incubated with anti-BrdU mouse monoclonal antibody (1:100, Sigma Chemical Co.) and then with horseradish peroxidase-conjugated antimouse IgG (1:100, Sigma Chemical Co.). Finally cells were visualized by diamino-benzidine staining (Sigma Chemical Co.) and light microscopy (Axiolab Karl Zeiss).

\section{Western blot analysis}

Western blot analysis was performed as previously described. ${ }^{24}$ The primary antibodies were diluted as follows: mouse anti-phospho-ERK (p-ERK1/2, 1:500, Santa Cruz Biotechnology, Santa Cruz, CA, USA), mouse anti-phospho-p38 (p-p38, 1:500, 1:500, Santa Cruz Biotechnology), rabbit anti-ERK (ERK1/2, 1:1000, Santa Cruz Biotechnology), mouse anti-p38 (p38, 1:500, 1:500, Santa Cruz Biotechnology), rabbit anti- $\gamma \mathrm{H} 2 \mathrm{AX}(1: 500, \gamma \mathrm{H} 2 \mathrm{AX}$, 
Cell Signaling Technology) and mouse anti- $\beta$-actin (1:1500, Aviva System Biology, San Diego, CA, USA). Immunoreactivity was detected by using horseradish peroxidase-conjugated anti-mouse or anti-rabbit as appropriate (Sigma Chemical Co.), and ECL system (Amersham ECL Prime western blotting detection reagent; GE Healthcare, Buckinghamshire, UK). Densitometric analyses were performed using the software ImageJ $1.32 \mathrm{~J}$ (NIH, Bethesda, MD, USA).

\section{Determination of apoptosis}

Apoptotic cells after a $48 \mathrm{~h}$ treatment were determined by TdT-mediated UTP-biotin Nick End labeling (TUNEL) assay according to the manufacturer's instructions (CHEMICON International, CA, USA). Cells were visualized using Axiolab Karl Zeiss microscope (Göttingen, Germany).

Phosphatidylserine exposure on the surface of apoptotic cells was detected by flow cytometry after staining with Annexin V-FITC (BD biosciences, USA), and PI $(50 \mu \mathrm{g} / \mathrm{ml})$. Data were analyzed using BD AccuriCSampler software (Becton Dickinson Co., Franklin Lakes, NJ, USA).

\section{Measurement of intracellular ROS production}

After a $24 \mathrm{~h}$ treatment, cells were incubated with $5 \mu \mathrm{mol} / \mathrm{l}$ dichlorodihydrofluoresceindiacetate (DCFH2-DA) (Sigma Chemical Co.) and ROS levels were measured by flow cytometry and data analysis was performed using BD AccuriCSampler software (Becton Dickinson Co.).

\section{Determination of 8-OHdG by flow cytometry}

Cells were treated for $24 \mathrm{~h}$ and then washed, detached by trypsinazation, and were then fixed with methanol at $-20^{\circ} \mathrm{C}$ for $10 \mathrm{~min}$. Fixed cells were treated with RNase $(100 \mu \mathrm{g} / \mathrm{ml})$ for $1 \mathrm{~h}$ at $37^{\circ} \mathrm{C}$ and proteinase $\mathrm{K}(10 \mu \mathrm{g} / \mathrm{ml})$ (Sigma Chemical Co.) for $10 \mathrm{~min}$ at room temperature. After rinsing with PBS, DNA was denatured by treatment with $4 \mathrm{nmol} / \mathrm{H} \mathrm{HCl}$ for $10 \mathrm{~min}$ followed by $\mathrm{pH}$ adjustment with $50 \mathrm{mmol} / \mathrm{l}$ Tris (pH 10) for $5 \mathrm{~min}$ at room temperature. After blocking in $5 \%(\mathrm{w} / \mathrm{v})$ equine serum in PBS, cells were incubated $30 \mathrm{~min}$ at RT with goat 8-OHdG (1:100, Millipore). Cells were washed with PBS and incubated for $30 \mathrm{~min}$ with 1:300 fluorescein isothiocyanate (FITC)-conjugated anti-goat Immunoglobuline $\mathrm{G}(\mathrm{lgG})$ and mean fluorescence was determined by flow cytometry and data analysis was performed using BD AccuriCSampler software (Becton Dickinson Co.)

\section{$\mathrm{RT}$ and real-time quantitative PCR (qPCR)}

After a $24 \mathrm{~h}$ treatment, cells were removed and immediately homogenized in Trizol Reagent (Life Technologies Co., Carlsbad, CA, USA) to isolate the RNA, according to the manufacturer's instructions. The RNA pellets were dissolved in RNase-free water and the RNA concentration was quantified by measuring the absorbance at $260 \mathrm{~nm}$ (NanodropND-1000, Thermo Fisher Scientific Inc., Wilmington, DE, USA). CDNA was synthesized by retrotranscription using the Omniscript kit (Qiagen, Valencia, CA, USA) following the manufacturer' instructions using $2 \mu \mathrm{g}$ total RNA and $1 \mu \mathrm{mol} / \mathrm{l}$ oligodeoxythymidine (Biodynamics SRL, Buenos Aires, Argentina). PCRs were performed using a commercial mastermix for real-time PCR containing SYBR Green fluorescent dye (Biodynamics SRL) in a total volume of $25 \mu \mathrm{l}$, which contained $10 \mathrm{pmol}$ of each primer and $1 \mu \mathrm{l}$ of CDNA and employing a RotorGene-6000 DNA thermal cycler (Corbett, Life Sciences, Sydney, NSW, Australia). The cycling conditions were $95^{\circ} \mathrm{C}$ for $15 \mathrm{~min}$, followed by 40 cycles of denaturation at $95^{\circ} \mathrm{C}$ for $10 \mathrm{~s}$, annealing at $60^{\circ} \mathrm{C}$ for $15 \mathrm{~s}$, and extension at $72{ }^{\circ} \mathrm{C}$ for $30 \mathrm{~s}$. Primer sequences (Biodynamics SRL) were designed using the Primer Express Software version 3.0 (Applied Biosystems, Foster City, CA, USA) (Supplementary Table S4). Quantification of the target gene expression was performed using the comparative cycle threshold $(\mathrm{Ct})$ method. An average $\mathrm{Ct}$ value was calculated from the duplicate reactions and normalized to the expression of $\beta 2$-microglobulin. The $\Delta \Delta \mathrm{Ct}$ value was then calculated as previously reported. ${ }^{50}$

\section{Statistical analysis}

Unless otherwise indicated, all data shown are mean \pm S.E.M. Statistical evaluations were made by analysis of variance that was followed by Newman-Keuls' Multiple Comparison Test unless otherwise indicated, using GraphPad Prism Version 5.00 software (San Diego, CA, USA). P-values $<0.05$ were considered statistically significant.

\section{ABBREVIATIONS}

Dox, doxorubicin; ROS, reactive oxygen species; HA, histamine; H4R, histamine $\mathrm{H} 4$ receptor; $\mathrm{TNBC}$, triple-negative breast cancer; CK-MB, creatine kinase myocardial band; AST, aspartate aminotransferase; SOD, superoxide dismutase; TBARS, thiobarbituric acid reactive species; WT, wild type; $\mathrm{Cl}$, combination index; $\mathrm{BrdU}$, 5-bromo-2'-deoxyuridine; TUNEL, terminal deoxynucleotidyl transferase dUTP nick end labeling; 8-OHdG, 8hydroxy-2-deoxyguanosine; ERK, extracellular signal-regulated kinase; $\mathrm{p}$ ERK1/2, phospho-ERK1/2; p-p38, phospho-p38; PCNA, proliferating cell nuclear antigen; $\mathrm{H} 3 \mathrm{R}$, histamine $\mathrm{H} 3$ receptor; $\mathrm{I} / \mathrm{R}$, ischemia/reperfusion; $\mathrm{H} 1 \mathrm{R}$, histamine $\mathrm{H} 1$ receptor; $\mathrm{H} 2 \mathrm{R}$, histamine $\mathrm{H} 2$ receptor; $\mathrm{H} 4 \mathrm{R}-/-, \mathrm{H} 4 \mathrm{R}$ knockout; $\mathrm{KO}$, knockout; i.p., intraperitoneally; s.c., subcutaneous; $\mathrm{H} \& \mathrm{E}_{\text {, }}$ hematoxylin-eosin staining; DTNB, 5,5'-dithiobis(2-nitro-benzoic acid); DCFH2-DA, dichlorodihydrofluoresceindiacetate; $\mathrm{Ct}$, cycle threshold; $\mathrm{PI}$, propidium iodide; RT, room temperature; IgG, immunoglobulin G; $\mathrm{qPCR}$, quantitative PCR.

\section{ACKNOWLEDGEMENTS}

This work has been supported by grants from the University of Buenos Aires 20020130200148BA (VAM), 20020130100799BA (ESR), 20020130100777BA (JCP), 20020130100289BA (GAC), CONICET PIP 11220110101121 (VAM); National Cancer Institute, Argentina (VAM); National Agency for Science and Technology ANPCYT (GAC). We thank the National Cancer Institute of Argentina for financial support through a fellowship to Melisa Nicoud. We thank Drs Nicholas Carruthers and Robin Thurmond of Janssen Research \& Development for the $\mathrm{H}_{4} \mathrm{R}^{-1-}$ mice.

\section{COMPETING INTERESTS}

The authors have no conflict of interest to declare.

\section{REFERENCES}

1 Ferlay J, Soerjomataram I, Dikshit R, Eser S, Mathers C, Rebelo M et al. Cancer incidence and mortality worldwide: sources, methods and major patterns in GLOBOCAN 2012. Int J Cancer 2015; 136: E359-E386.

$2 \mathrm{Kim} \mathrm{JH}$, Jenrow KA, Brown SL. Mechanisms of radiation-induced normal tissue toxicity and implications for future clinical trials. Radiat Oncol J 2014; 32: 103-115.

3 Octavia Y, Tocchetti CG, Gabrielson KL, Janssens S, Crijns HJ, Moens AL. Doxorubicin-induced cardiomyopathy: from molecular mechanisms to therapeutic strategies. J Mol Cell Cardiol 2012; 52: 1213-1225.

4 Stěrba $M$, Popelová $O$, Vávrová $A$, Jirkovský $E$, Kovaříková $P$, Geršl V et al. Oxidative stress, redox signaling, and metal chelation in anthracycline cardiotoxicity and pharmacological cardioprotection. Antioxid Redox Signal 2013; 18: 899-929.

5 Yang F, Teves SS, Kemp CJ, Henikoff S. Doxorubicin, DNA torsion, and chromatin dynamics. Biochim Biophys Acta 2014; 1845: 84-89.

6 Minotti G, Menna P, Salvatorelli E, Cairo G, Gianni L. Anthracyclines: molecular advances and pharmacologic developments in antitumor activity and cardiotoxicity. Pharmacol Rev 2004; 56: 185-229.

7 El-Sayyad HI, Ismail MF, Shalaby FM, Abou-El-Magd RF, Gaur RL, Fernando A et al. Histopathological effects of cisplatin, doxorubicin and 5-flurouracil (5-FU) on the liver of male albino rats. Int J Biol Sci 2009; 5: 466-473.

8 Damodar G, Smitha T, Gopinath S, Vijayakumar S, Rao Y. An evaluation of hepatotoxicity in breast cancer patients receiving injection Doxorubicin. Ann Med Health Sci Res 2014; 4: 74-79.

9 Hall EJ, Giaccia AJ, Hall EJ, Giaccia AJ (eds). Radiobiology for Radiologists. Lippincott Williams and Wilkins: Philadelphia, PA, USA, 2012.

10 Shi Y, Moon M, Dawood S, McManus B, Liu PP. Mechanisms and management of doxorubicin cardiotoxicity. Herz 2011; 36: 296-305.

11 Citrin DE, Mitchell JB. Altering the response to radiation: sensitizers and protec tors. Semin Oncol 2014; 41: 848-859.

12 Medina VA, Croci M, Mohamad NA, Massari N, Garbarino G, Cricco GP et al. Mechanisms underlying the radioprotective effect of histamine on small intestine. Int J Radiat Biol 2007; 83: 653-663.

13 Medina VA, Croci M, Carabajal E, Bergoc RM, Rivera ES. Histamine protects bone marrow against cellular damage induced by ionising radiation. Int J Radiat Biol 2010; 86: 283-290

14 Carabajal E, Massari N, Croci M, Martinel Lamas DJ, Prestifilippo JP, Bergoc RM et al. Radioprotective potential of histamine on rat small intestine and uterus. Eur J Histochem 2012; 56: e48.

15 Medina VA, Prestifilippo JP, Croci M, Carabajal E, Bergoc RM, Elverdin JC et al. Histamine prevents functional and morphological alterations of submandibular glands induced by ionising radiation. Int J Radiat Biol 2011; 87: 284-292. 
16 Martinel Lamas DJ, Croci M, Carabajal E, Crescenti EJ, Sambuco L, Massari NA et al. Therapeutic potential of histamine $\mathrm{H}_{4}$ receptor agonists in triple-negative human breast cancer experimental model. Br J Pharmacol 2013; 170: 188-199.

17 Medina V, Croci M, Crescenti E, Mohamad N, Sanchez-Jiménez F, Massari N et al. The role of histamine in human mammary carcinogenesis: $\mathrm{H} 3$ and $\mathrm{H} 4$ receptors as potential therapeutic targets for breast cancer treatment. Cancer Biol Ther 2008; 7: 28-35.

18 Medina V, Cricco G, Nuñez M, Martín G, Mohamad N, Correa-Fiz F et al. Histaminemediated signaling processes in human malignant mammary cells. Cancer Biol Ther 2006; 5: 1462-1471.

19 Medina VA, Brenzoni PG, Lamas DJ, Massari N, Mondillo C, Nunez MA et al. Role of histamine $\mathrm{H} 4$ receptor in breast cancer cell proliferation. Front Biosci (Elite Ed) 2011; 3: 1042-1060.

20 Martinel Lamas DJ, Rivera ES, Medina VA. Histamine H4 receptor: insights into a potential therapeutic target in breast cancer. Front Biosci (Schol Ed) 2015; 7: 1-9.

21 Medina VA, Rivera ES. Histamine receptors and cancer pharmacology. Br J Pharmacol 2010; 161: 755-767.

22 Massari NA, Medina VA, Cricco GP, Martinel Lamas DJ, Sambuco L, Pagotto R et al. Antitumor activity of histamine and clozapine in a mouse experimental model of human melanoma. J Dermatol Sci 2013; 72: 252-262.

23 Meng $F$, Han $Y$, Staloch $D$, Francis $T$, Stokes A, Francis $H$. The H4 histamine receptor agonist, clobenpropit, suppresses human cholangiocarcinoma progression by disruption of epithelial mesenchymal transition and tumor metastasis. Hepatology 2011; 54: 1718-1728.

24 Martinel Lamas DJ, Cortina JE, Ventura C, Sterle HA, Valli E, Balestrasse KB et al. Enhancement of ionizing radiation response by histamine in vitro and in vivo in human breast cancer. Cancer Biol Ther 2015; 16: 137-148.

25 Xin YF, Wan LL, Peng JL, Guo C. Alleviation of the acute doxorubicin-induced cardiotoxicity by Lyciumbarbarum polysaccharides through the suppression of oxidative stress. Food Chem Toxicol 2011; 49: 259-264.

26 Bouwens L, Baekeland M, De Zanger R, Wisse E. Quantitation, tissue distribution and proliferation kinetics of Kupffer cells in normal rat liver. Hepatology 1986; 6: 718-722.

27 Sharma S, Barry M, Gallagher DJ, Kell M, Sacchini V. An overview of triple negative breast cancer for surgical oncologists. Surg Oncol 2015; 24: 276-283.

28 Chou TC. Drug combination studies and their synergy quantification using the Chou-Talalay method. Cancer Res 2010; 70: 440-446.

29 Kasai H. Analysis of a form of oxidative DNA damage, 8-hydroxy-2'-deoxyguanosine, as a marker of cellular oxidative stress during carcinogenesis. Mutat Res 1997; 387: 147-163.

30 Rojo F, González-Navarrete I, Bragado R, Dalmases A, Menéndez S, Cortes-Sempere M et al. Mitogen-activated protein kinase phosphatase-1 in human breast cancer independently predicts prognosis and is repressed by doxorubicin. Clin Cancer Res 2009; 15: 3530-3539.

31 Mantawy EM, El-Bakly WM, Esmat A, Badr AM, El-Demerdash E. Chrysin alleviates acute doxorubicin cardiotoxicity in rats via suppression of oxidative stress, inflammation and apoptosis. Eur J Pharmacol 2014; 728: 107-118.

32 Manjanatha MG, Bishop ME, Pearce MG, Kulkarni R, Lyn-Cook LE, Ding W. Genotoxicity of doxorubicin in F344 rats by combining the comet assay, flowcytometric peripheral blood micronucleus test, and pathway-focused gene expression profiling. Environ Mol Mutagen 2014; 55: 24-34.

33 Iliskovic N, Singal PK. Lipid lowering: an important factor in preventing adriamycin-induced heart failure. Am J Pathol 1997; 150: 727-734

34 Robador PA, Seyedi N, Chan NY, Koda K, Levi R. Aldehyde dehydrogenase type 2 activation by adenosine and histamine inhibits ischemic norepinephrine release in cardiac sympathetic neurons: mediation by protein kinase C $\varepsilon$. J Pharmacol Exp Ther 2012; 343: 97-105.
35 Yadav $\mathrm{CH}$, Najmi AK, Akhtar M, Khanam R. Role of H3R agonist imetit on isoproterenol-induced hemodynamic changes and oxidative stress in rats. Toxicol Mech Methods 2014; 15: 1-23.

36 Aldi S, Takano K, Tomita K, Koda K, Chan NY, Marino A et al. Histamine H4receptors inhibit mast cell renin release in ischemia/reperfusion via protein kinase C $\varepsilon$-dependent aldehyde dehydrogenase type-2 activation. J Pharmacol Exp Ther 2014; 349: 508-517.

37 El-Moselhy MA, El-Sheikh AA. Protective mechanisms of atorvastatin against doxorubicin-induced hepato-renal toxicity. Biomed Pharmacother 2014; 68: 101-110.

38 Daemen T, Hofstede G, Ten Kate MT, Bakker-Woudenberg IA, Scherphof GL. Liposomal doxorubicin-induced toxicity: depletion and impairment of phagocytic activity of liver macrophages. Int J Cancer 1995; 61: 716-721.

39 El-Mahdy NA, El-Sisi AE, Dewidar BI, El-Desouky KI. Histamine protects against the acute phase of experimentally-induced hepatic ischemia/re-perfusion. J Immunotoxicol 2013; 10: 9-16.

40 Deiteren A, De Man JG, Pelckmans PA, De Winter BY. Histamine $\mathrm{H}_{4}$ receptors in the gastrointestinal tract. $\mathrm{Br} J$ Pharmacol 2015; 172: 1165-1178.

41 Thurmond RL. The histamine H4 receptor: from orphan to the clinic. Front Pharmacol 2015; 6: 65 .

42 Martinel Lamas DJ, Carabajal E, Prestifilippo JP, Rossi L, Elverdin JC, Merani S et al. Protection of radiation-induced damage to the hematopoietic system, small intestine and salivary glands in rats by JNJ77777120 compound, a histamine H4 ligand. Plos One 2013; 8: e69106.

43 Martner A, Wiktorin HG, Lenox B, Ewald Sander F, Aydin E, Aurelius J et al. Histamine promotes the development of monocyte-derived dendritic cells and reduces tumor growth by targeting the myeloid NADPH oxidase. J Immunol 2015; 194: 5014-5021.

44 Galmarini CM. Histamine dihydrochloride (subcutaneous) Maxim. Curr Opin Investig Drugs 2004; 5: 1298-1310.

45 Martner A, Thorén FB, Aurelius J, Hellstrand K. Immunotherapeutic strategies for relapse control in acute myeloid leukemia. Blood Rev 2013; 27: 209-216.

46 Yang LP, Perry CM. Histamine dihydrochloride: in the management of acute myeloid leukaemia. Drugs 2011; 71: 109-122.

47 Yagi K. A simple fluorometric assay for lipoperoxide in blood plasma. Biochem Med 1976; 15: 212-216.

48 Tietze F. Enzymic method for quantitative determination of nanogram amounts of total and oxidized glutathione: applications to mammalian blood and other tissues. Anal Biochem 1969; 27: 502-522.

49 Medina VA, Massari NA, Cricco GP, Martín GA, Bergoc RM, Rivera ES. Involvement of hydrogen peroxide in histamine-induced modulation of WM35 human malignant melanoma cell proliferation. Free Radic Biol Med 2009; 46: 1510-1515.

50 Sterle HA, Valli E, Cayrol F, Paulazo MA, Martinel Lamas DJ, Diaz Flaqué MC et al. Thyroid status modulates $\mathrm{T}$ lymphoma growth via cell cycle regulatory proteins and angiogenesis. J Endocrinol 2014; 222: 243-255.

(c) (i) This work is licensed under a Creative Commons Attribution 4.0 article are included in the article's Creative Commons license, unless indicated otherwise in the credit line; if the material is not included under the Creative Commons license, users will need to obtain permission from the license holder to reproduce the material. To view a copy of this license, visit http://creativecommons.org/licenses/ by/4.0/

Supplemental Information accompanies the paper on the Cell Death Discovery website (http://www.nature.com/cddiscovery) 